日臨外医会誌 $51(5), 971-974,1990$

症例

分婏時に発生した食道アカラシア術後横隔膜瘶痕ヘルニアの 1 例

\begin{tabular}{cccccccc}
\multicolumn{10}{c}{ 大阪府 } & \multicolumn{1}{c}{ 日生病院外科 } \\
竹 内 & 幸 & 康 & 森 & 匡 水 谷 伸 \\
小 川 & 法 & 次 & 宗 & 田滋 夫 & & &
\end{tabular}

症例は30歳の女性で, 28歳時, 食道フカラシアと診断され, Thal-旗福法により手術を 施行された。 30 歳時, 妊娠 6 カ月より食物の胃内停滞が著明となった, 妊娠 9 カ月で経 腟分婏にて出産した，分婏直後より左胸背部痛が出見し，呼吸困難と血圧低下をきたし た. 胸部 X 線検查にて横隔膜ヘルニフと診断し緊急手術を行った。 食道裂孔左側の哆開 した横隔膜の㴒痕創より，緊満した胃及び大網が左胸腔内に脱出し心蔵を王排していた。 幽門部には器質的狭窄を認めなかった。手術後は手術直前の数分間の心停止のため, 失 外套症候群となった. Thal-旗福法は, 術後人工的な食道裂孔へルニアとなる。妊娠と緊 满した胃が腹圧を著明に上昇させ横隔膜へルニアが生したものと考えられた，妊娠を希 望する食道フカラシアの患者に外科治療を行ら場合は, 横隔膜を切開しない術式が望 しい，横隔膜を切開する術式で，迷走神経損傷が疑われたときは，幽門形成術を追加す ベきである.

索引用語：横隔膜へルニフ, 食道フカラシフ, 妊娠

はじめに

食道アカラシアの術後に横隔膜へルニアを合併する ことは稀である。今回, 食道フラカシフの術後 1 年目 に弤娠し，分婏時に発生した横隔膜㾿痕へルニアの1 例を経験したので, 若干の文献的考察を加え報告する. 症例

患者：30歳，女性.

主訴: 呼吸困難, 左胸痛.

既往歴：10歳時虫垂切除術を施行された。

家族歴：特記すべきことなし。

現病歴：24歳頃より哭下困難が出現し,1987年 6 月, 28歳時に，他院にて食道フカラシフと診断され，Thal瀻福法による手術を受けた。術後は概ね順調であった が1989年 2 月, 妊娠 6 力月頃より食後上腹部痛, 呕吐 が頻回に出現した。胃内視鏡検查にて，食道炎扣よび 胃内に多量の食物残稙を認め, 十二指腸潰場の治療を 受けていた。

5 月 2 日， 36 週 4 日にて女児を早産した。胎児仮死 のためりリステリル法にて，急速遂婏涼を行った，分 婏直後より左胸部が突き上げられるような胸痛を訴

1989年 8 月 4 日受付 1990 年 1 月18日採用
え, 3 時間後より左背部痛, および 5 時間後より呼吸 困難と血圧低下を来し，当科に紹介された。

食道フカラシフ術前（1987年 3 月30日）の X 線造影 像では，食道の拡張と正常な蠕動波の消失を認めた。 $\mathrm{S}$ 状型, 第II度のアカラシアと診断されていた(図 1). 術後 3 カ月目には食道の拡張は軽减し, 造影剂は噴門 を良好に通過していた（図2）。

初診時現症：体格，栄養中等度，顔貌は苦閂状で， 呼吸は $36 /$ 分之速迫していた，負血軽度，黄疾認めず， 四肢末梢は冷たく， 口唇および爪床にチフノーゼを認 めた。左側胸部には手術痕を認めた。呼吸音は左胸部 で聴取不能であった，腹部は右季肋部に弾性硬の肝を 5 横指触知した。

血圧は $98 \mathrm{mmHg}$ であったが, 動脈血ガスデータは酸 素投与下にもかかわらず， $\mathrm{PO}_{2} 79 \mathrm{mmHg}, \mathrm{PCO}_{2} 27$ $\mathrm{mmHg}, \mathrm{pH} 7.129 \mathrm{BE}-19.7 \mathrm{mEq} / l$ と不良であった. 胸部 X 線検查にて, 左胸腔内は注ほ均一な $\mathrm{X}$ 線透過 度の低い陰影によって占められ，左肺は頭側に著明に 王排されていた。粈隔は右方へ，肝藏は尾側へ偏位し ていた（図 3).

横隔膜へルニフの嵌頓と診断し, 祭急手術を行った。 手術時には, 呼吸循環不全がさらに進行しており, 血 

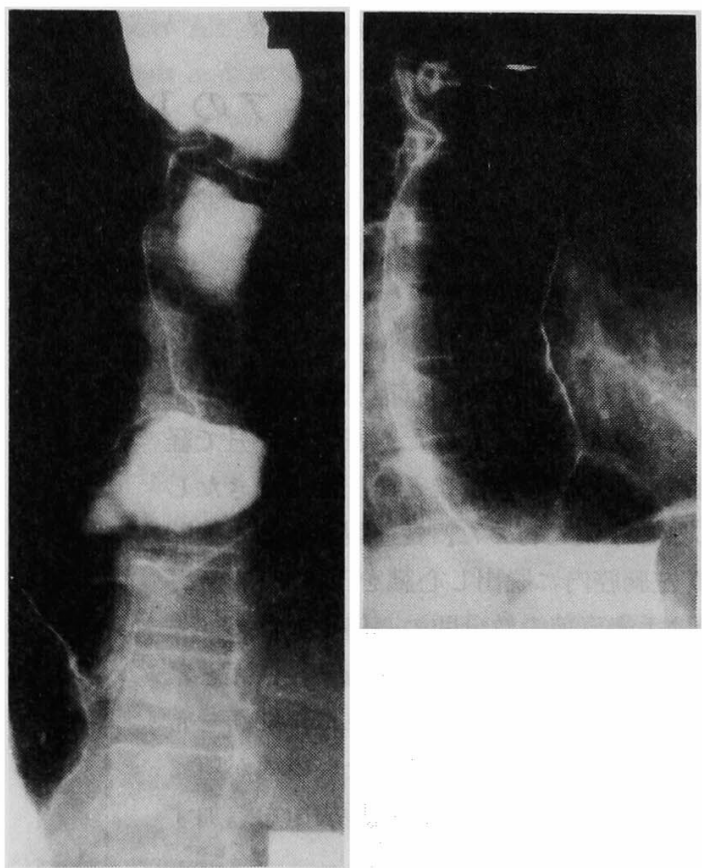

図 1 食道アカラシア術前 $\mathbf{X}$ 線造影像
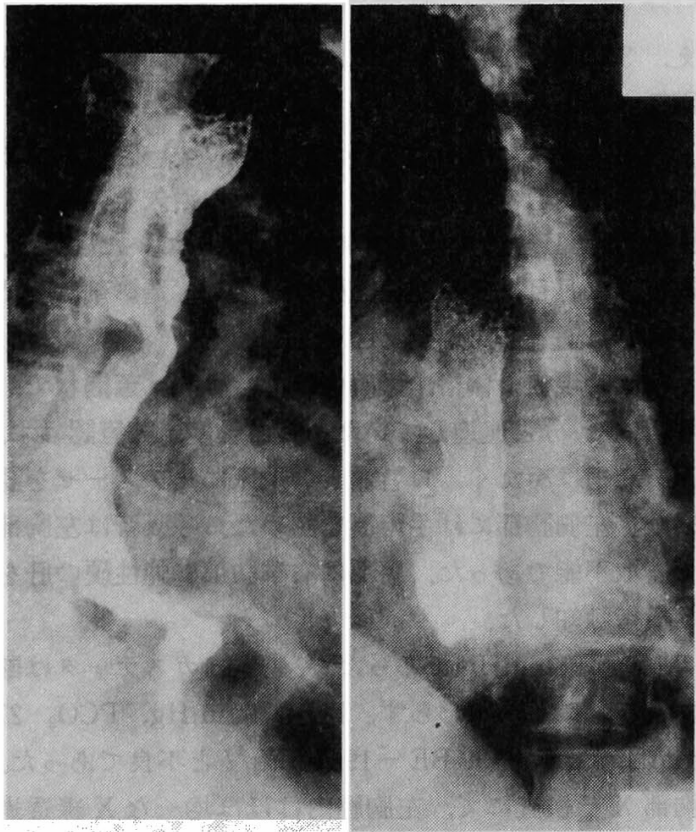

図 2 食道アカラシア術後 3 カ月の $\mathrm{X}$ 線造影像

圧は $60 \mathrm{mmHg}$ まで低下していた. 気管内插管後心停止 となり,閉胸式打よび開胸式心マッサージ,カウンター

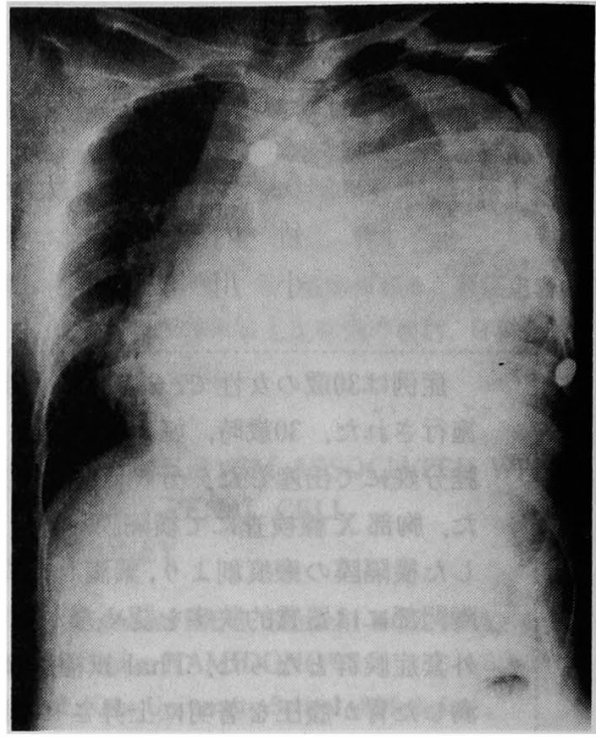

图 3 術前胸部 $\mathbf{X}$ 線像

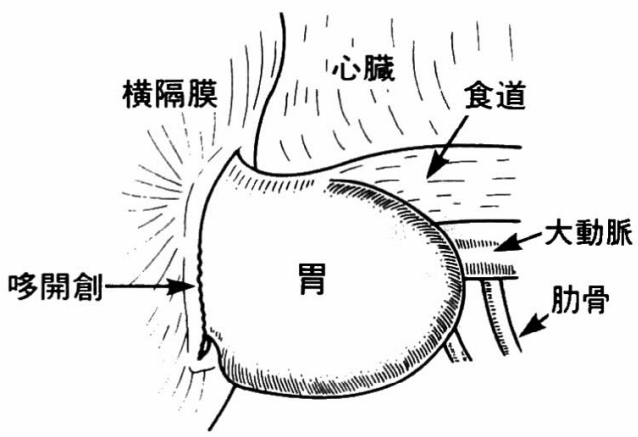

图 4 手術所見のシェーマ：哆開創より胸腔内に脱出 した胃は，心臓を著明に圧排し，心停止を来してい た.

ショック等にて蘇生後, 手術を開始した。

手術所見：左胸腔内および粶隔は高度に緊満した胃 と大網により占居されこのため心臓が著明に压排さ 九心停止を来していた，胃内には茶褐色の液体と食物 残渣が約 6 リットル充満していた。胃および大網は, 食道裂孔左側の哆開した創部より胸腔内に脱出してい た(図 4 )。これらを腹腔内に還納後，哆開した手術創 を直接縫合閉鎖した。十二指腸潰瘍は触診上明かでは なかった。幽門部には狭窄はなかったが，通過改善目 的で幽門形成を追加した。

術後経過: 術前のショック状態と, 麻酔導入時の数 分間の心停止による脳障害が原因と考兄られる失外套 


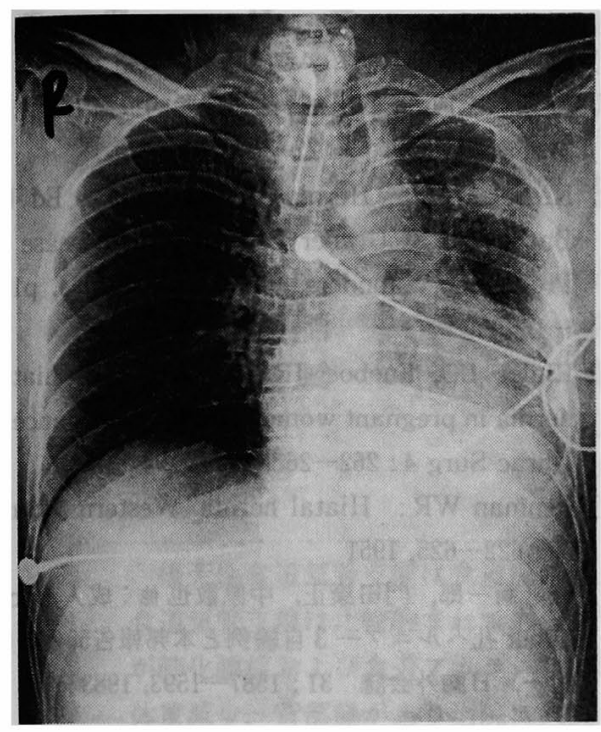

図 5 術後 2 カ月の胸部 $\mathbf{X}$ 線像

症候群が術後 2 力月現在まで続いている. 術後 2 力月 の胸部 X 線像では, 左横隔膜の挙上を認める (図 5 ).

\section{考案}

本例に施行された Thal-度福法は，重症アカラシア に対しても効果を期待できる術式のひとつとされてい

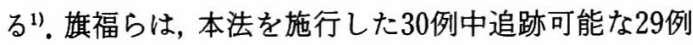
の遠隔成績は，著効と良好を合わせ $96.6 \%$ あったと 報告している.

本法の術後合併症として, 横隔膜へルニアが生じた という報告は今のところなく，本例は稀な症例と思わ れる. 本法は噴門形成後, 横隔膜閉鎖の際, 胃底部を 無理に腹腔内に還納せず, 横隔膜と胃底部奨膜を固定 するのみである。旗福らは，このようにして作られた 人工的食道裂孔ヘルニアによる愁訴は30例中，全く経 験していないと述べている。

本例は術後 1 年 8 力月, 妊娠 6 力月頃より幽門狭窄 様の病態となっていた。 この原因として, 当初は十二 指腸潰瘍が疑われたが，術中所見では潰瘍は存在しな かった，その他に，アカラシア手術時の迷走神経損傷 が考兄らるが, 術後 1 年 8 力月後より発症したとい 5点に疑問が残る、結局，幽門部の通過障害の原因は 不明であった。粸福らの報告では, Thal-旗福法術後の 幽門部通過障害については特に言及されて拈らず，ま た検索した限りでは，文献上見あたらなかった。この 点でも本例は稀な症例と言える.

一方，妊娠中に発生するへルニアは表 1 のごとく分
表 1 Classification of hernias in pregnancy

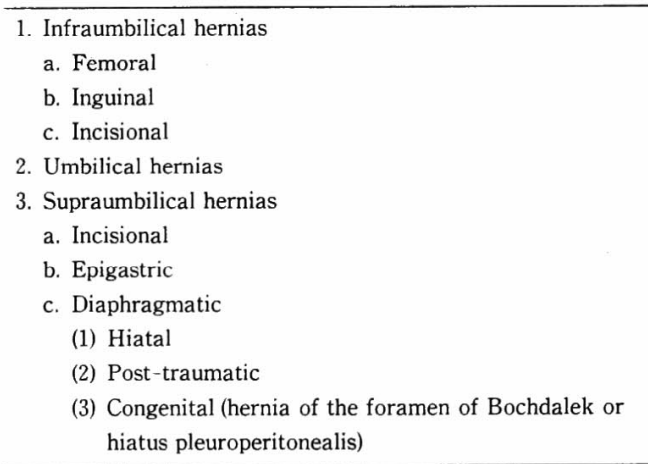

(Kesseler, H.J.)

表 2 好娠が誘因となった Bochdalek 孔へルニア

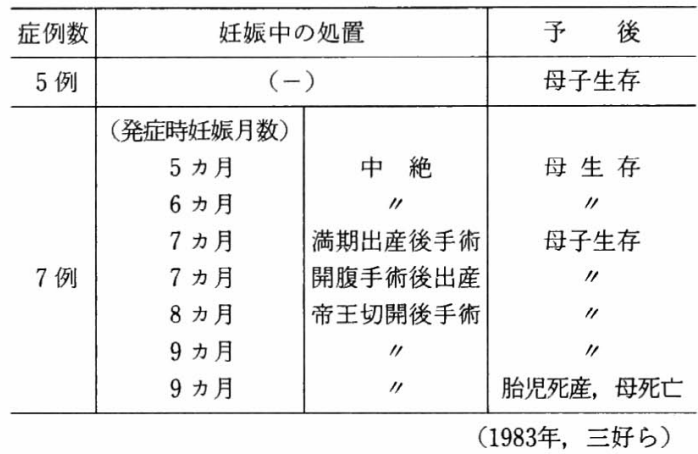

類される2).これららちで最も頻度の高いのは食道裂 孔ヘルニアである. Rigler ら゙は, 非選択的に妊娠第三 期の妊婦 195 人に上部消化管透視を施行し, $12.5 \%$ に食 道裂孔へルニアを認めた。 またそのらちの数例は，分 婏後に再度 $\mathrm{X}$ 線検查を施行したところ, ヘルニアは消 失していた。 よって, 妊娠中の腹王の上昇がへルニア の発生に多大に関与するとしている. 本例は, 妊娠に 加え胃が緊満していたため, 横隔膜の縫合部が哆開し, ヘルニアが生じた可能性は十分考えられる，妊娠中の

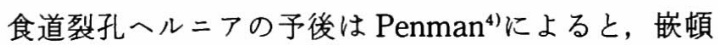
や絞扼は比較的稀で, 1910年から1950年の間に文献上 13例が報告されているのみである。一方，妊娠中に発 症した Bochdalek 孔ヘルニアは稀であるが, 非常に重

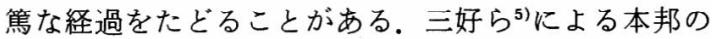
成人 Bochdalek 孔へルニアの検討によると, 妊娠が誘 因となったと考えられた Bochdalek 孔へルニアは, 過 去に12例あった（表 2 ）。その5ち 7 例が妊娠中に Bochdalek 孔へルニアの対処を迫られた。妊娠 8 力月以 降の 3 症例は帝王切開後, ヘルニアの手術がなされて 
いた。 そのらちの1例は皎拒性イレウスを合併してい たため, 胎児は死産し，母親死亡した。

食道アカラシア術後に妊娠し発生した横隔膜へルニ アは本例の他に報告がない，本例は発症が急速で，か つ呼吸循環不全を早期に来した。さらに，緊急に外科 的治療を行ったにもかかわらず重篤な後遺症を残し た。このような経過より，将来出産を希望するアカラ シアの患者に外科的治療を行ら場合は，術式の選択に 十分な配慮が必要であると考えられた。 また，Thal-旗 福法を行う場合は，迷走神経損傷に注意し，少しでも 損傷が疑われた場合は開腹し，幽門形成術を追加する ことを倹討すべきである。さらに，本法術後の患者が 妊娠した場合は，対処の方法を産科医と検討し，妊娠 月数によっては帝王切開などを针めるべきである。

以上，分娩時に発生したと考えられた食道アカラシ フ術後横隔膜揤痕へルニフの 1 例を経験したので報告 した。

\section{文献}

1）砤福哲彦，日下純男，八島良幸他：食道フカラシフ に対する Fundic patch 法の理論的根拠と手術成 樍，日消外会誌 $8: 72-79,1975$

2) Kesseler $\mathrm{HJ}$ : Hernias in pregnancy, Ed by Barber HRK, Graber EA, Surgical Disease in Pregnancy, Saunders, Philadelphia, 1974, p161 $-168$

3) Rigler LG, Eneboe JR: Incidence of hiatus hernia in pregnant women and its significance. J Thrac Surg $4: 262-268,1935$

4) Penman WR: Hiatal hernia. Western J Surg $59: 622-625,1951$

5）三好新一郎，門田康正，中原数也他：成人 Bochdalek 孔ヘルニアー3 自験例と本邦報告58例の検 討一, 日胸外会誌 $31: 1587-1593,1983$

\title{
A CASE OF DIAPHRAGMATIC CICATRICIAL HERNIA DEVELOPING AT DELIVERY AFTER SURGERY FOR ESOPHAGEAL ACHALASIA
}

\author{
Yukiyasu TAKEUCHI, Tadasu MORI, Shin MIZUTANI, Noritsugu OGAWA and Shigeo SODA \\ Department of Surgery, Nissei Hospital
}

A 30-year-old woman, who had undergone surgery for esophageal achalasia with Thal-Hatafuku method at the age of 28 , had retention of foods in the stomach which became marked in the sixth month of pregnancy. She delivered via the vagina in the ninth month of pregnancy. Pain in the left chest and back appeared just after delivery, and the patient had dyspnea and a decrease in blood pressure. Diaphragmatic hernia was diagnosed on the basis of chest X-ray examination, and emergency operation was performed. The distended stomach and major omentum herniated into the left thoracic vavity and pressed the heart. Organic stenosis was not found in the pyloric stenosis was not found in the pyloric part of the stomach. Postoperatively, the patient fel into apallisches syndrome because of cardiac standstill for several minutes just before surgery. The Thal-Hatafuku method may induce postoperative artificial esophageal hiatal hernia. In the present case, it is thought that pregnancy and the distended stomach greatly elevated the abdominal pressure causing diaphragmatic hernia. Operation without incising the diapragm is desirable as surgical treatment for female patients with esophageal acharasia who are hopeful of pregnancy. In the operative method with incision of the diaphragm, pyloroplasty should be added in which an injury of the vagus nerve is suspected. 